\title{
Geochemistry and Tectonic Setting of Kohe Siahvolcanoes, North Qorveh, Sanandaj, Iran
}

\author{
Somaye Kazemi Koohbanani ${ }^{1}$, Seyed Jamal Sheikhzakariee ${ }^{1 *}$, Mohammad Hashem Emami ${ }^{2}$, \\ Rahim Dabiri ${ }^{3}$
}

${ }^{1}$ Department of Geology, Science and Research Branch, Islamic Azad University, Tehran, Iran

${ }^{2}$ Department of Geology, Islamic Azad University, Islamshahr Branch, Tehran, Iran

${ }^{3}$ Department of Geology, Islamic Azad University, Mashhad Branch, Mashhad, Iran

Email: *j.sheikhzakaria@gmail.com

How to cite this paper: Koohbanani, S.K., Sheikhzakariee, S.J., Emami, M.H. and Dabiri, R. (2018) Geochemistry and Tectonic Setting of Kohe Siahvolcanoes, North Qorveh, Sanandaj, Iran. Open Journal of Geology, 8, 474-488.

https://doi.org/10.4236/ojg.2018.85028

Received: November 25, 2016

Accepted: December 6, 2016

Published: May 15, 2018

Copyright (C) 2018 by authors and Scientific Research Publishing Inc. This work is licensed under the Creative Commons Attribution International License (CC BY 4.0).

http://creativecommons.org/licenses/by/4.0/

\begin{abstract}
The KoheSiah Volcanoes are located in the North of Qorveh city in the west of Iran. The KoheSiah volcanoes include several craters bearing domes located in the Kordestan Province, between latitudes $35^{\circ} 23^{\prime} 13.54^{\prime \prime}$ to $35^{\circ} 21^{\prime} 26.63^{\prime \prime} \mathrm{N}$ and longitudes $47^{\circ} 54^{\prime} 38.26^{\prime \prime} \mathrm{E}$ to $47^{\circ} 56^{\prime} 01.42^{\prime \prime} \mathrm{E}$. Based on the petrographic and geochemical analysis, the volcanic rocks in the KoheSiah area are classified as basalt, Alkali basalt, trachy-andesites and mugearite. The studied samples are alkaline with sodic to potasic feature based on $\mathrm{Na}_{2} \mathrm{O} / \mathrm{K}_{2} \mathrm{O}$ ratios and belonging to Shoshonite series. Most of the alkaline volcanic rocks in the study area fall in the field of within in plate basalts (WPB) and represent of a mantle metasomatism trend associated with variable degrees in the partial melting of an enriched mantle source.
\end{abstract}

\section{Keywords}

Alkaline Rocks, Kohesiah Volcanoes, Dome, Qorveh, Tectonic Setting

\section{Introduction}

The study area is located in the Northern part of Qorveh city among the by lowland and flat area. The volcanic domes cluster gives a special morphology to the study area. These volcanoes are generally called Siahkoh volcanoes on the Qorveh 1:100,000 quadrangle map (Figure 1). Regarding to the number of volcanoes in the study area and in order to discriminate and distinguish each of them, we used numerical numbering of volcanic domes in the KoheSiah area [1]. The total of teen volcanoes was studied (Figure 2). The volcanic complex contains several craters bearing domes with 2157 meter above sea level. This volcanic 


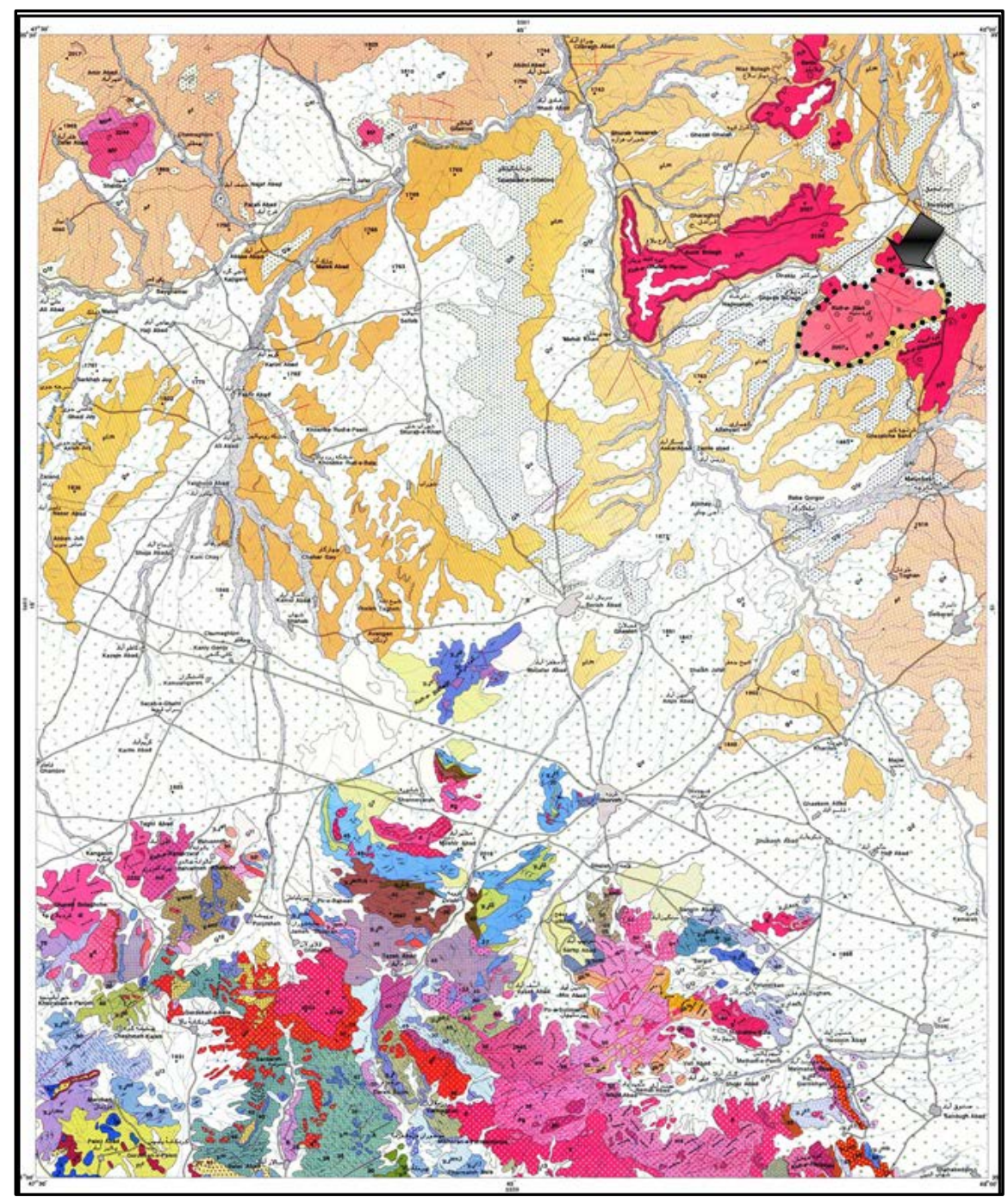

Figure 1. Geological map of 1:100,000 Ghorveh. The study of volcanoes is marked with dotted black.

complex has surrounded among the several alkaline basalt volcanoes. These alkaline volcanoes include: 1) KoheQarineh with two main conduits in the south eastern sector of cone, 2) QarehBolagh volcanic cone in the Norhern part of KoheSiah area, 3) Saraijogh volcanic cone in the Noth east and Dirkolovolcano. The KoheSiah volcanic complex is key area for studying of tertiary volcanism in the Sanandaj-Sirjanzone. This provides a unique opportunity to study of Andean type arc magmatism that took place at the Neo-Tethyan subduction margins. Notwithstanding, despite the significance of KoheSiah volcanic rocks to understanding of arc magmatism along the Neo-Tethyan margin, due to limited field and geochemical data, tectonic evolution, this unit is relatively poorly constrained and there are many unknown about their tectonic setting. Our study presents major and trace element data for a number of volcanic rocks from KoheSiah volcanic domes, with the aim to study and evaluate the geochemical features and tectonic setting of KoheSiah volcanic rocks. 


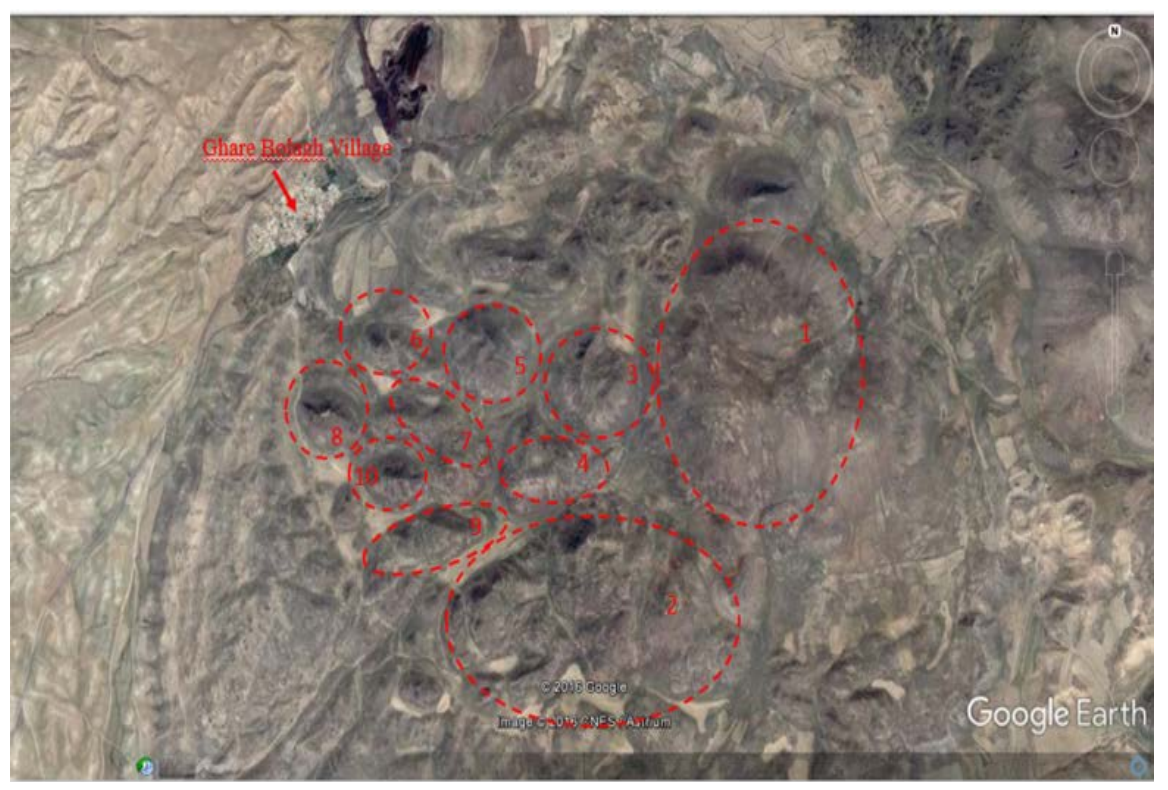

Figure 2. Satellite view (Google earth) of 10 studied volcanoes (dotted red) in the studied volcanic complex.

\section{Methodology and Analytical Procedures}

In this research detailed field studies include preparation of new geological map were combined with systematic and random sampling to aim multidisciplinary approach of this research. The twenty one sample after petrographical studies were selected for geochemical analysis. Forty Trace and Minor element for selected samples were analyzed using inductively coupled plasma mass spectrometry (ICP-MS) methods.

\section{Discussion}

\subsection{Regional Geology}

The Qorveh area is geologically, divided in two northern and southern sector. The northern and southern have main different magmatic and structural evolution history. The volcanic centers in the northern sector are part of NW-SE trending Takab-Qorveh volcanic belt with acidic, intermediate and basic lavas. The acidic and intermediate volcanoes are distributed as Domes, dyke and ignimbrite sheets. The basic volcanoes the basic volcanoes as low altitude scoria cones $(50 \mathrm{~m})$ and their lavas due to law gravity extent several kilometer above Qorve plain. The main volcanic center in the Takab-Qorveh region as follows [2]:

1) Takhte Soleyman (Nosrat Abad) peripheral volcanic centers with high K andesite and dacite;

2) Ayob Ansar volcano with dacite composition;

3) Qare Tore volcano with basalt composition;

4) Nadri volcano with basalt composition;

5) Tahmorath volcano with basalt composition; 
6) Jorovandi volcano with basalt in the basal part and trachy basalt in the upper part;

7) Ahmad Abad volcano with basalt composition and granitoids enclaves;

8) Gozel ghayeh-GhareBolagh volcano with basanite composition;

9) GhareBolagh volcano with dacite composition;

10) Ghizilja Kand volcano with basalt-andesite composition and several granitoids enclave;

11) Sheyda-Yakhi kamal volcanoes with dacite and andesite composition;

12) Kani Derij peripheral volcanoes with high $K$ dacite composition.

In the southern sector of Qoeveh area, stratigraphical sequences from base to top include the Triassic, Triass-Jurassic and Jurassic metamorphic rocks and Eocene none metamorphed rocks. The Triassic and Jurassic units are lack of fossil and their ages is determinate by field relation and stratigraphic position.

\subsection{Local Geology}

The study area (KoheSiah volcanic complex) is located in the north east of Qorve city within the Sanandaj-Sirjan structural zone. This area is part of volcanic center between Takab and QaraAghaj cities which refereed as Takab-Qorveh volcanic belt within the northern part of Sandaj-Sirjan structural zone. The KoheSiah volcanic complex situated $25.6 \mathrm{Km}$ of NE ofQorveh city between KoheQarineh in the NW and QareBolagh in the SW (Figure 3). The KoheSiah volcanic complex include several craters bearing domes with 2157 meter average elevation which located between latitudes $35^{\circ} 23^{\prime} 13.54^{\prime \prime}$ to $35^{\circ} 21^{\prime} 26.63^{\prime \prime} \mathrm{N}$ and longitudes $47^{\circ} 54^{\prime} 38.26^{\prime \prime} \mathrm{E}$ to $47^{\circ} 56^{\prime} 01.42^{\prime \prime} \mathrm{E}$. the crater of volcanoes formed in the latest phases of volcanic activity as complete summit craters in the top of volcanoes (Figure 4).

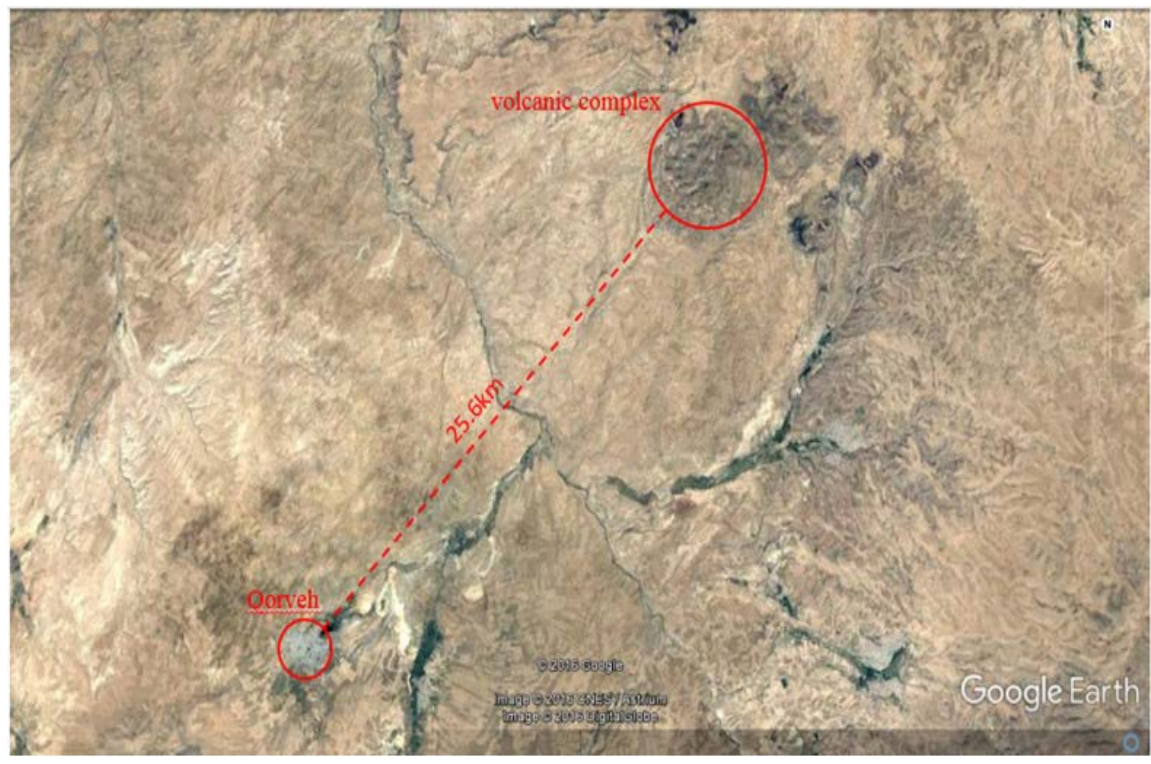

Figure 3. Satellite image (Google earth) studied the volcanic complex (red circle) which is located Qorveh $25.6 \mathrm{~km}$ of the city. 


\subsection{Classification and Nomenclature of Studied Samples}

Several rock classification diagrams are used for classification and nomenclature of volcanic rocks of rocks of KoheSiah area. They are including:

\subsubsection{Total Alkali versus $\mathrm{SiO}_{2}$ (TAS) Classification Diagram}

The Kohesiah volcanic rocks were classified using the total alkalis $\left(\mathrm{K}_{2} \mathrm{O}+\mathrm{Na}_{2} \mathrm{O}\right.$ wt.\%) vs. $\mathrm{SiO}_{2}$ diagram of Cox et al. (1979) (Figure 5) [3]. All the volcanic rocks lie within the mugearite, trachy-andesite and hawaiite, the curved line (from macdonald and Katasura., 1964) divides alkali from sub-alkali associations. However, in the Total alkali versus $\mathrm{SiO}_{2}$ diagram (Le bas et al., 1986) [4] all samples fall in the basalt and trachy andesite fields (Figure 6).

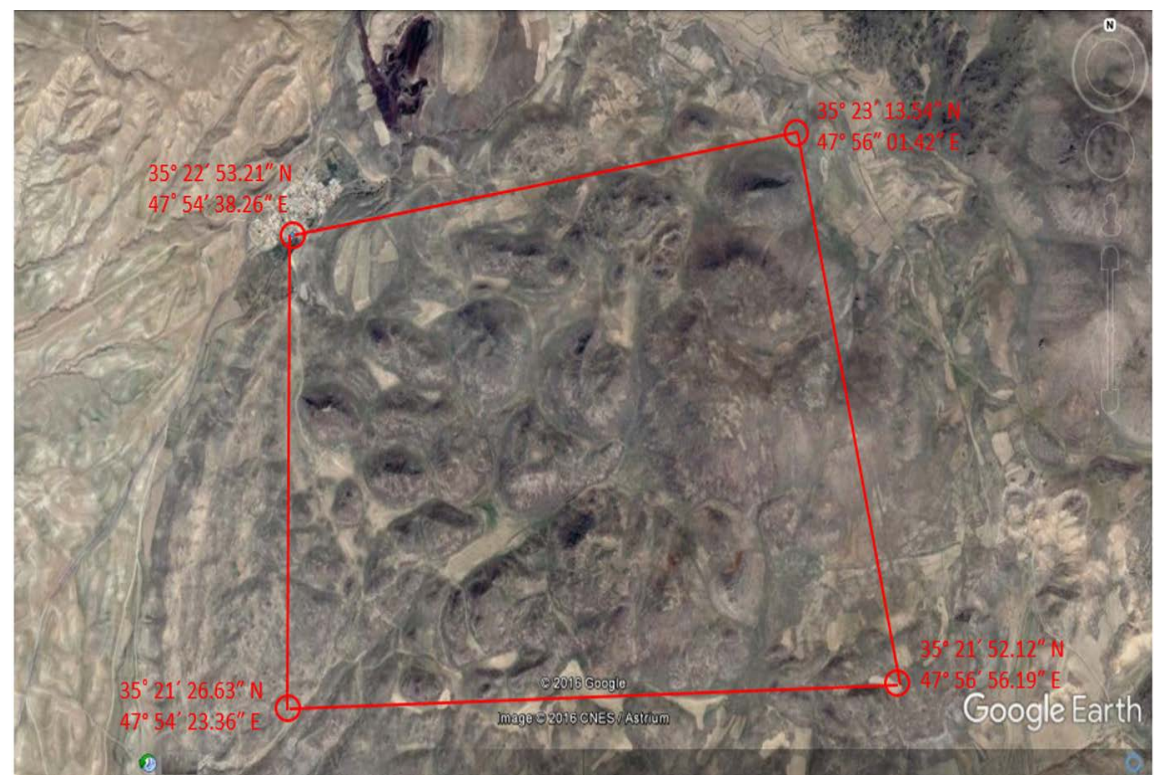

Figure 4. Satellite image (Google earth) of the quadrangular series studied volcano.

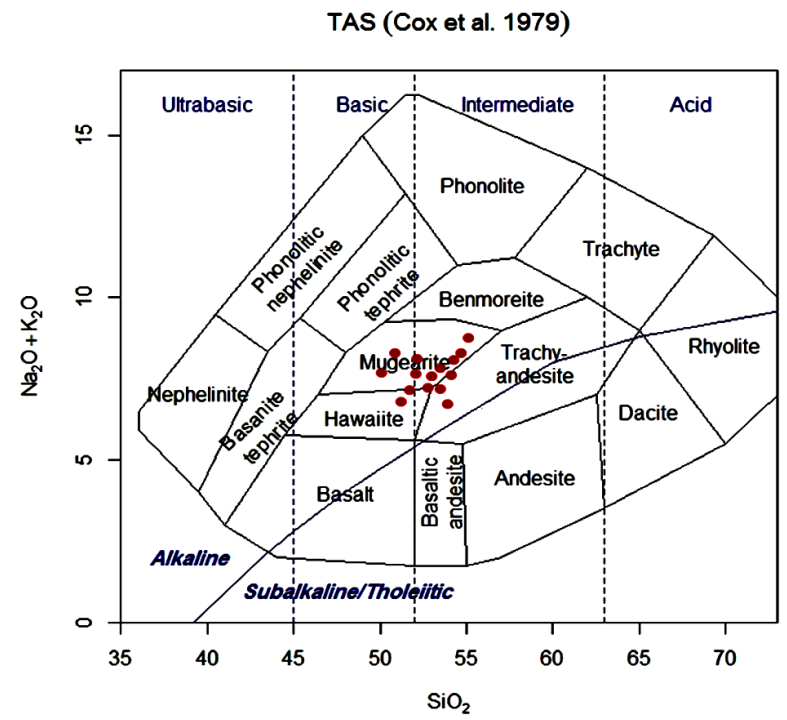

Figure 5. Classification for total alkali versus $\mathrm{SiO}_{2}$ (Cox et al., 1979). 
3.3.2. $R_{1}-R_{2}$ Classification Diagram (De La Roche et al., 1988)

This compositional variation of Siah Koh volcanic rocks is investigated by using the millication proportions of their major oxides according to the rock classification of De La Roche, et al. (1980) (Figure 7) [5]. The studied samples lie in the hawaiite, mugearite and Lati basalt fields.

\subsubsection{Nb/Y versus $\mathrm{Zr} / \mathrm{TiO}_{2}$ Classification (Winchester and Floyd., 1977)}

In The $\mathrm{Zr} / \mathrm{TiO}_{2}{ }^{\star} 0.0001$ vs. $\mathrm{Nb} / \mathrm{Y}$ (Figure 8) diagrams of Winchester and Floyd (1977) [6] and the Zr/TivsNb/Y (Figure 9) diagrams of Pearce (1996) [7] KoheSiah volcanic samples Fall within the basalt, trachy andesite and alkaline basalt fields.

TAS (Le Bas et al. 1986)

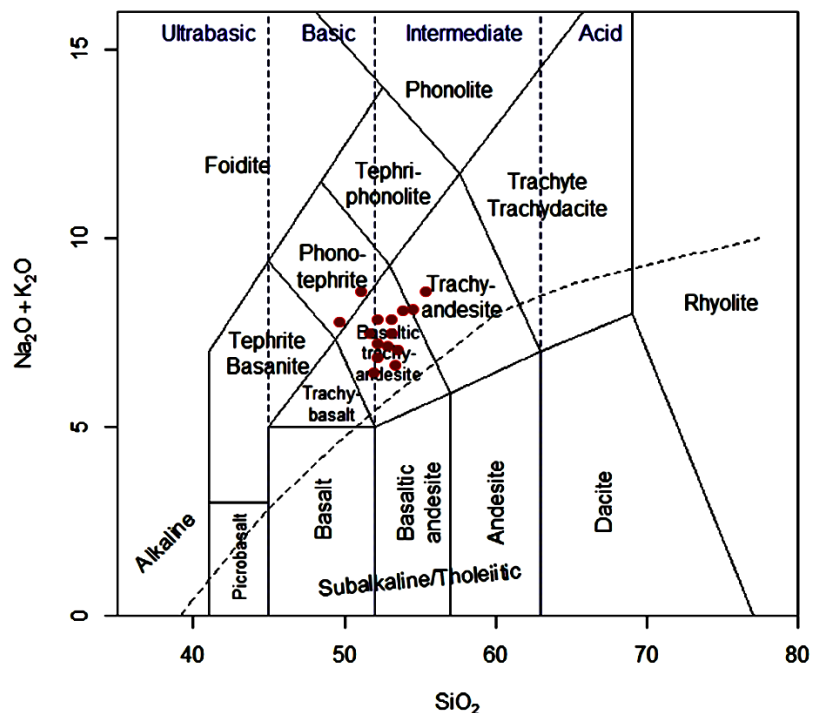

Figure 6. Classification for total alkali versus $\mathrm{SiO}_{2}$ (Le bas et al., 1986).

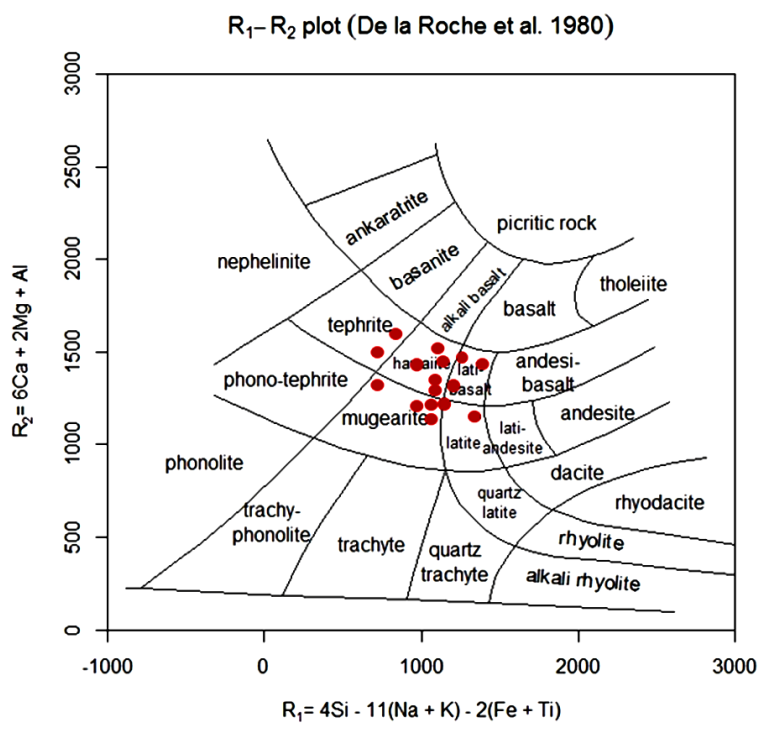

Figure 7. Classification by R1-R2 (De La Roche et al., 1980). 


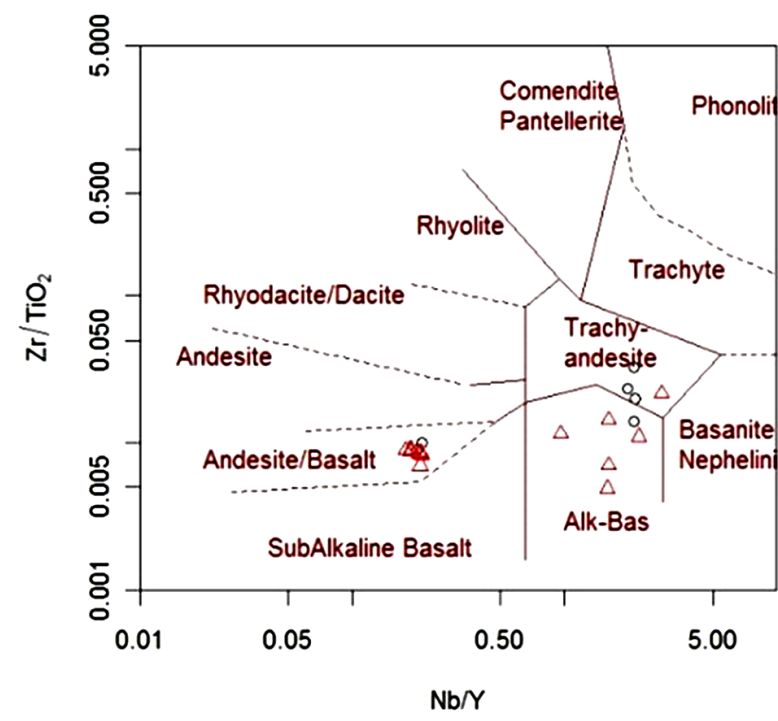

Figure 8. Classification based of $\mathrm{Nb} / \mathrm{Y}$ versus $\mathrm{Zr} / \mathrm{TiO}_{2}{ }^{*} 0.0001$ (Winchester and Floyd., 1977).

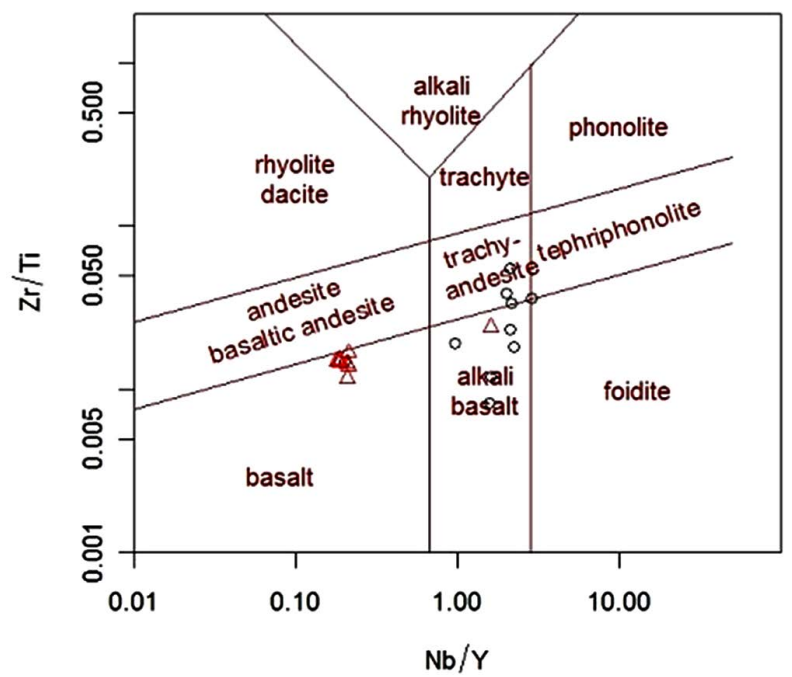

Figure 9. Classification based of $\mathrm{Zr} /$ Tiversus $\mathrm{Nb} / \mathrm{Y}$ (Pearce, 1996).

\subsection{Determination of Magmatic Series}

One of the main objects in the petrological studies is determination of magmatic series. According to Kuno (1968) [8] igneous rock series term that was used to signify the genetic relationship between a group of chemically (and petrographically) different but regionally associated igneous rocks which originated same parent magma. Hovewer, new funding indicate other parameter such as magma assimilation, different rates of partial and magmatic contamination could be create false magma series and grouping of different magmatic rock in the same magmatic association which not evolved from same parent magma. In order to determination of magma series of Nahran volcanic rock several different diagrams are used as follow: 


\subsubsection{The $\mathrm{K}_{2} \mathrm{O}$ versus $\mathrm{SiO}_{2}$ Discrimination Diagram}

In the $\mathrm{SiO}_{2}$ versus $\mathrm{K}_{2} \mathrm{O}$ diagram (peccerillo and Taylor., 1976) [9] could be discriminated three high $\mathrm{K}$ low- $\mathrm{K}$ series, the medium-K series, the high- $\mathrm{K}$ series, and the shoshonite series. The studied samples are alkaline with sodic to potasic feature based on $\mathrm{Na}_{2} \mathrm{O} / \mathrm{K}_{2} \mathrm{O}$ ratios and belonging to Shoshonite series (Figure 10).

\subsection{Determination of Tectonic Setting of KoheSiah Volcanic Rocks}

In order to evaluation of the tectonic setting of KoheSiah volcanic rocks several tectonic discriminate diagram have been used they are include:

\subsubsection{Zr/Y versus Zr Discriminate Diagram}

The KoheSiah volcanic rocks lie in the field of within plate basalts in the $\mathrm{Zr} / \mathrm{Y}$ versus $\mathrm{Zr}$ discriminate diagram (Pearce and Norry., 1979) [10]. Most of samples show relative enrichment in the $\mathrm{Zr}$ which is in related to metasomatism of mantle by low partial melting melts in the lower depth (Figure 11).

\subsubsection{The Ti/100-Zr-Y*3 Ternary Diagram}

In the Ti/100-Zr-Y*3 ternary discriminate diagram (Pearce and Cann., 1973) [11] the studied samples fall in the within plate (D) field (Figure 12).

\subsubsection{The Nb*2-Zr/4-Y Ternary Diagram (Meschede. 1989)}

The siah Koh volcanic rocks lie in the field of within plate alkaline basalts (Al) in the $\mathrm{Nb}^{\star 2} 2-\mathrm{Zr} / 4-\mathrm{Y}$ ternarydiscriminate diagram (Meschede., 1989) [12] (Figure 13).

\subsection{Multi Element Spider Diagrams}

The spider diagrams are used for identification of the petrogenic processes and

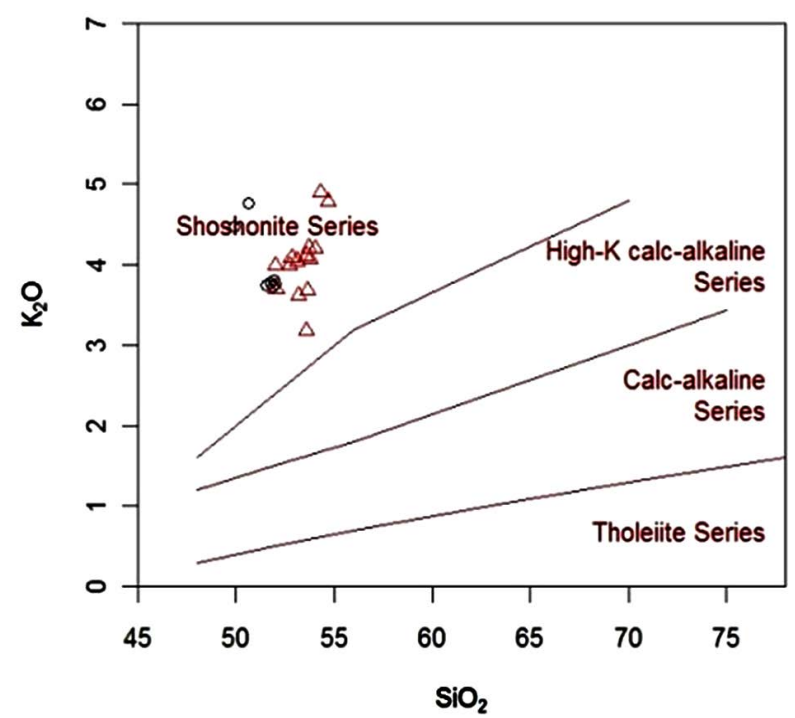

Figure 10. The $\mathrm{K}_{2} \mathrm{O}$ versus $\mathrm{SiO}_{2}$ Discrimination diagram (peccerillo and Taylor., 1976). 


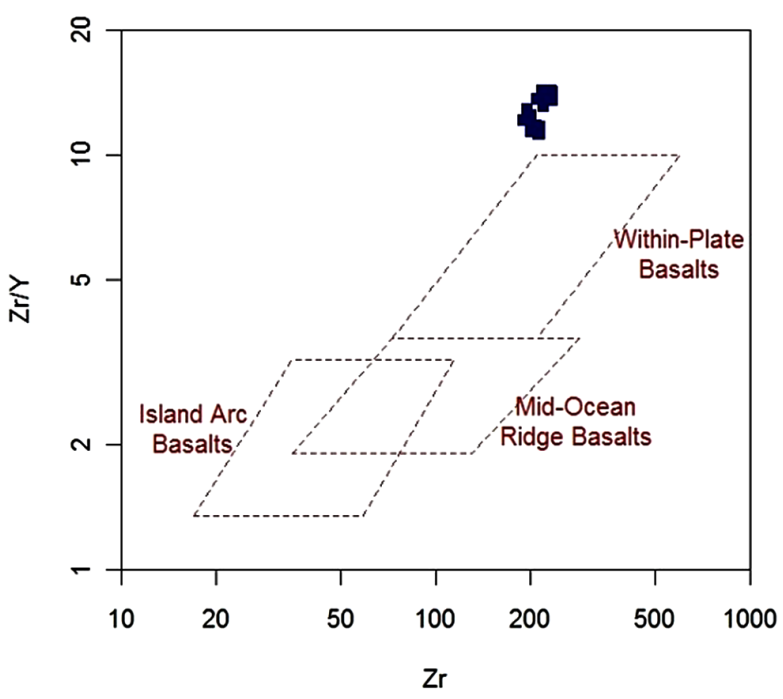

Figure 11. Determination of tectonic setting volcanic rocks using Zr-Zr/Y diagram (Pearce \& Norry, 1979).

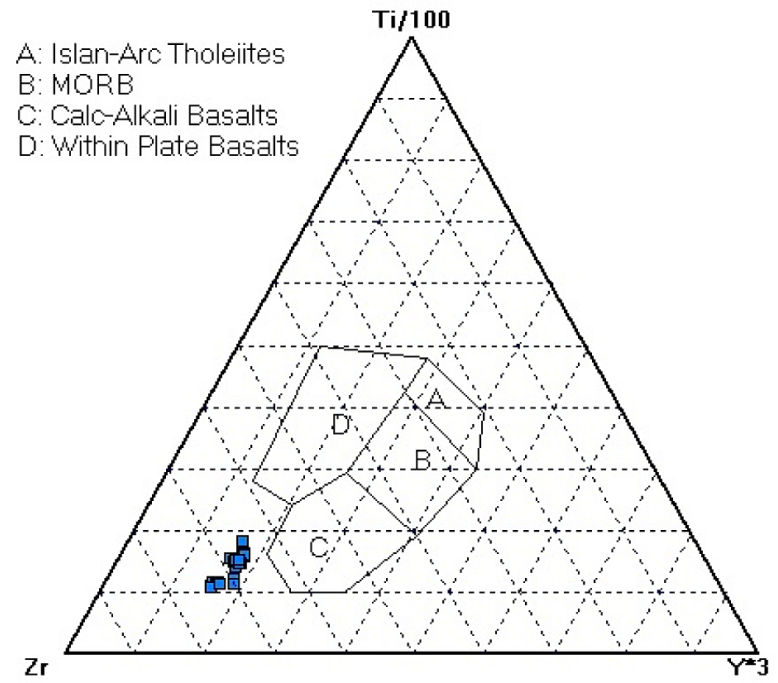

Figure 12. Determination of tectonic setting volcanic rocks using diagram ( Pearce and Cann., 1973).

inferring of different tectonic setting. Therefore, abundance of rare earth elements in the studied samples are normalized to the average abundance of these elements in the different tectonic settings, and interpreted magmatic processes such as fractionational crystallization, partial melting and magmatic contaminations by the diagram patterns such as their trends and positive and negative anomalies in the some elements (Rollinson., 1993) [13]. In order to having a Homogenous shape in the Elements abundance diagram the element abundance would be normalized to the primary rocks. The normalization pattern therefore has two importance functions. Firstly it eliminates the abundance variation between odd and even atomic number element and secondly it allows to evaluate the relative enrichment or deplation respect to standard. 


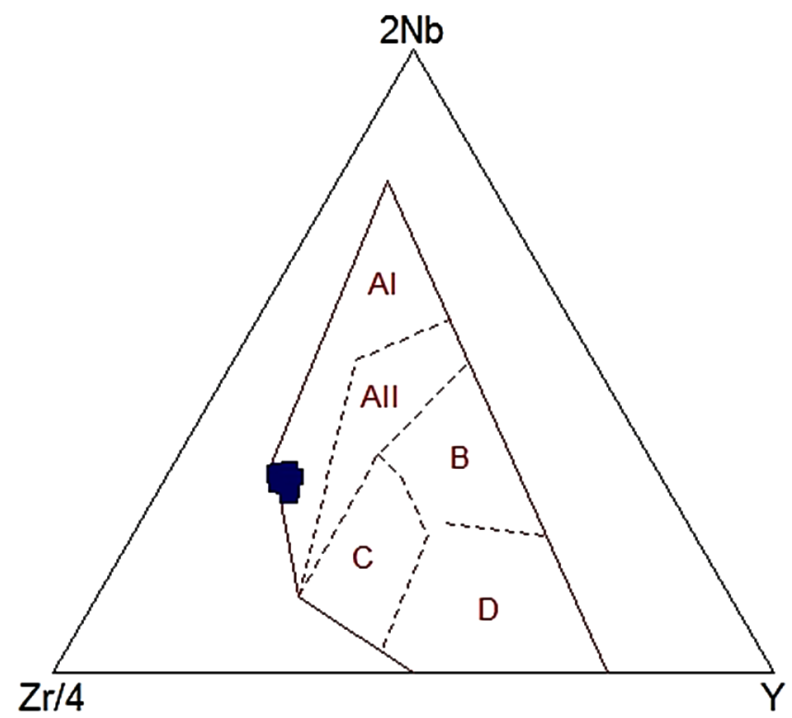

Figure 13. Determination of tectonic setting volcanic rocks using $\mathrm{Zr} / 4-2 \mathrm{Nb}-\mathrm{Y}$ diagram (Meschede. 1989).

\subsubsection{Chondrite Normalization for Siah Koh Volcanic Rocks}

Thampson et al. (1984) [14] are used common chonderites values to proposed a chonderite normalized spider diagrams. Thompson (1982) [15] proposed that normalization to chondrite values may be preferable to primitive mantle composition since chondrite value are directly measured rather estimated (Rollinson., 1993) [13]. In this diagram compatibility increase from left to right. The chondrite normalized pattern of KoheSiah volcanic rocks (Figure 14) represent LREE and HFSE enriched pattern and depletion in $\mathrm{Ti}, \mathrm{Nb}, \mathrm{Th}, \mathrm{Ta}$ and Enrichment in the $\mathrm{Zr}, \mathrm{K}, \mathrm{P}, \mathrm{Rb}$ elements. The negative anomaly of $\mathrm{Nb}$ is typical of crustal rocks and indicator of crustal participation in the magmatic processes.

However, negative anomaly of Ti could be related to the titanomagnetite fractionation, remaining of Ti bearing of amphibole, iron oxide, titan and clinopyroxene in the source region, or high degree of partial melting of source or crustal contamination (Fodor., 1987; Wilson, 1989) [16]. Negative anomaly of $\mathrm{Ta}$ is consistent with crustal contamination.

\subsubsection{Primitive Mantle Normalization of Siah Koh Volcanic Rocks}

Wood et al. (1979) [17] are used estimated composition of mantle before continental crust formation as mean for comparing composition variations between basic lavas and intrusions. In this diagram elements are arranged in order of increasing compatibility with respect to a small percentage melt of the mantle. The primitivemantle-normalized plots (Sun and Mc Donough., 1989; Wood et al., 1979) [17] [18] of the KoheSiah samples are shown in Figure 15, Figure 16. The patterns are characterized by light rare-earth elements (LREEs) relative to heavy rare earth elements (HREEs). They are depleted in $\mathrm{Th}, \mathrm{Nb}, \mathrm{Ta}, \mathrm{Ti}$, and enriched in $\mathrm{Rb}, \mathrm{Zr}, \mathrm{P}, \mathrm{K}$ elements. The enrichment in the LIL elements reaches to 1000 times to primitive mantle. 


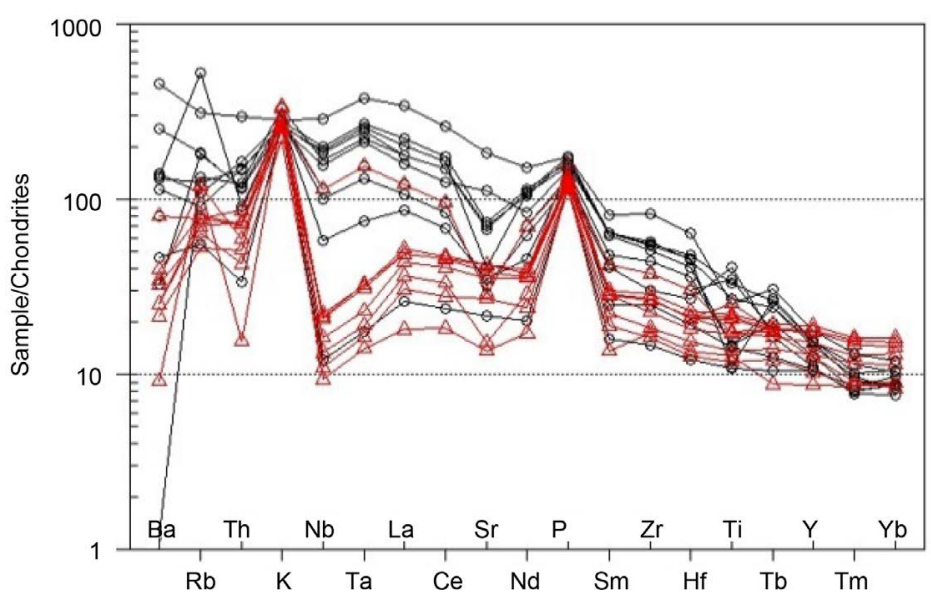

Figure 14. Spider diagram normalized relative to Chondrites (Thompson, 1982).

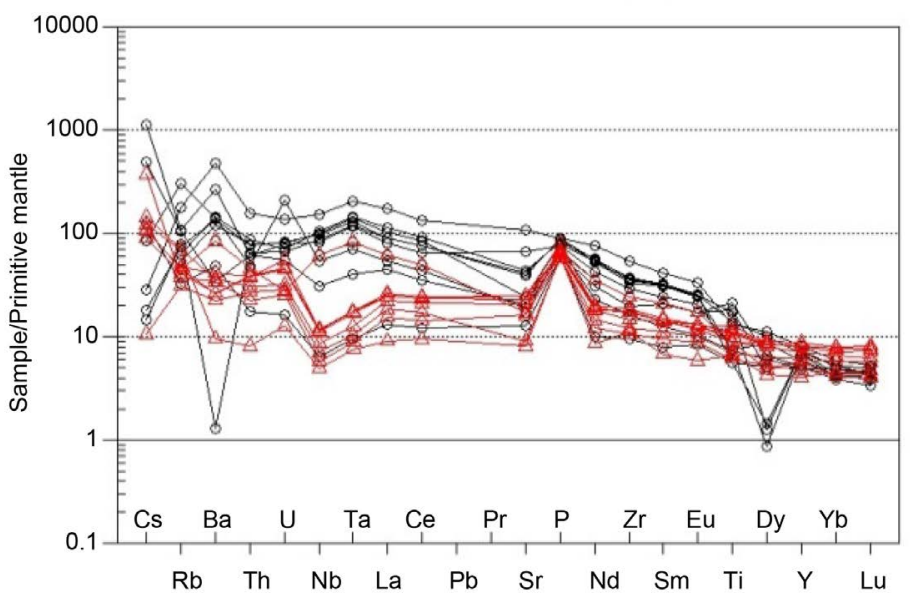

Figure 15. Spider diagram normalized relative to Primitive mantle (Sun \& McDonough 1989).

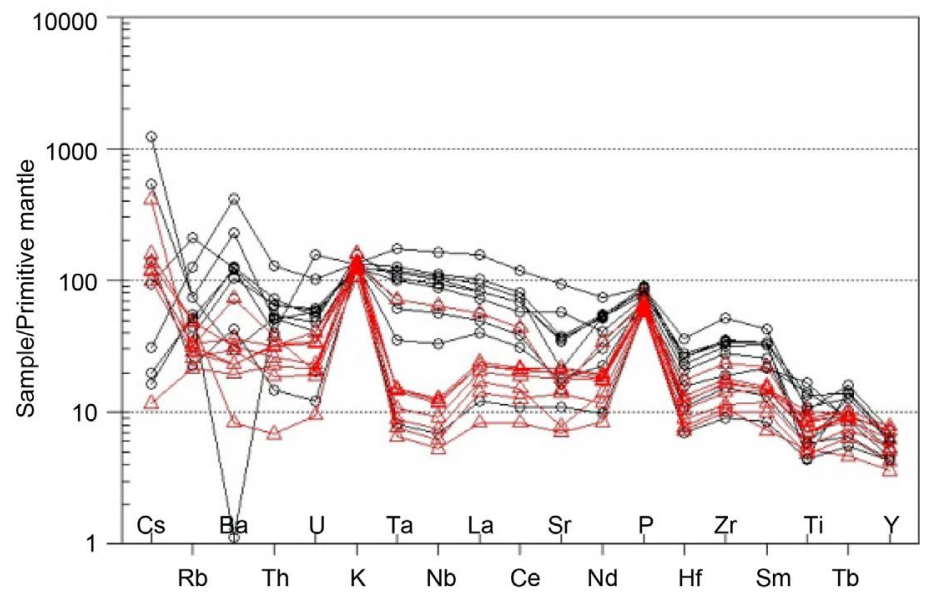

Figure 16. Spider diagram normalized relative to primitive mantle (Wood et al. 1979). 


\subsubsection{Normalization of KoheSiah Volcanic Rocks to Oceanic Island Basalt (OIB)}

Sun and Mc Donough (1989) [18] on the basis of trace and rare element concentrations in the oceanic island basalt proposed OIB normalized pattern.The OIB normalized pattern for KoheSiah volcanic rocks (Figure 17) represent nearly similar patterns with relative enrichment in the most of elements. Moreover, the descending pattern is obviously visible which could be reflection of different degree in the partial melting and fractional crystallization associated with crustal contamination (Wilson, 1989) [19].

\subsection{Geochemistry of Rare Earth Element in the KoheSiah Volcanic Rocks}

The rare earth element of KoheSiah Normalized to most accepted rare earth elements values of chondrite composition from Boynton (1984) [20] and Nakamura (1974) [21]. According to Figure 18, Figure 19 the relative enrichment in the HREE for most of KoheSiah volcanic rocks is less than mid ocean ridge basalts (N-MORB) and oceanic island basalts (OIB). The chondrite normalized pattern (Boynton., 1984) for KoheSiah volcanic rocks show relative enrichment in the LREEs such as La which show $100^{*}$ chondrite enrichment whereas, HREE elements such as $\mathrm{Yb}$ represent until $10^{*}$ chondrite. $\mathrm{The} \mathrm{La} / \mathrm{Yb}_{(\mathrm{Cn})}$ ratios range between 14.95 to 11.75 (averaging 13.1) for FR-10 and FR-13 samples, respectively. This could be in related to the heterogeneity of mantle source or changes in the partial melting degrees of different mantle sources. In the chondrite normalized diagram Figure 18, Figure 19 relative high slope of LREE/HREE in the most of samples are consistent with presence of residual garnet in the mantle source.

\section{Conclusion}

The volcanic rocks of KoheSiah volcanic complex include basalt, Alkali basalt,

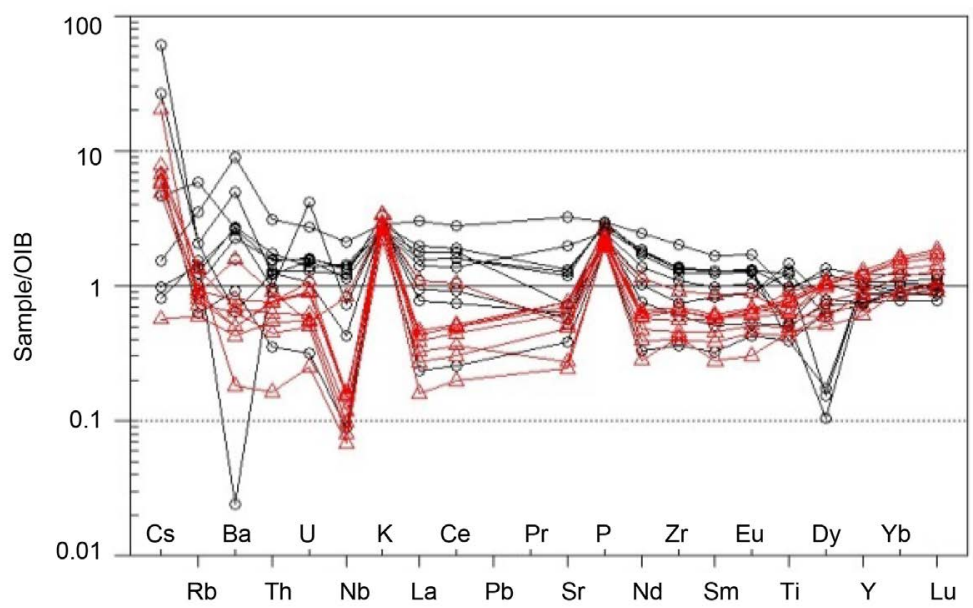

Figure 17. Spider diagram normalized relative to OIB (Sun \& McDonough 1989). 


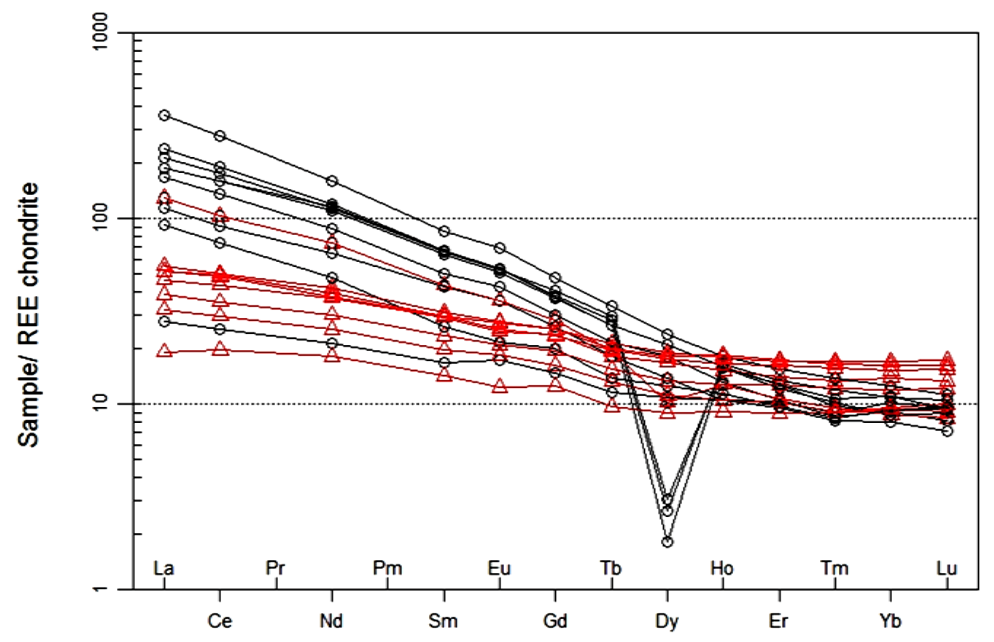

Figure 18. The rare earth element of KoheSiah Normalized to chondrite (Boyton, 1984).

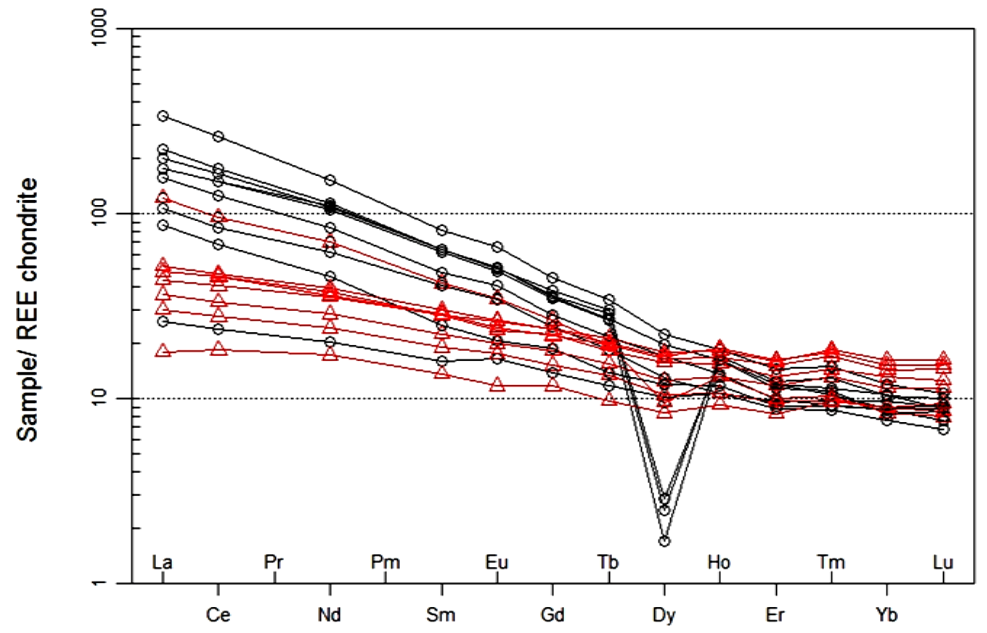

Figure 19. The rare earth element of KoheSiah Normalized to chondrite Nakamura (1974).

trachy-andesite and mugearite. The studied samples are alkaline with sodic to potasic feature based on $\mathrm{Na}_{2} \mathrm{O} / \mathrm{K}_{2} \mathrm{O}$ ratios and belonging to Shoshonite series. Most of the alkaline volcanic rocks in the study area fall in the field of within in plate basalts (WPB) and represent of a mantle metasomatism trend associated with variable degrees in the partial melting of an enriched mantle source. In the incompatible trace, element patterns for all volcanic rocks from the KoheSiah volcanic rocks represent negative anomalies in the Ti and $\mathrm{Nb}$ elements. However, negative anomaly of Ti could be related to the titanomagnetite fractionation, remaining of Ti bearing of amphibole, iron oxide, titan and clinopyroxene in the source rgion, or high degree of partial melting of source or crustal contamination. Negative anomaly of $\mathrm{Ta}$ is consistent with crustal contamination. The study of incompatibles trace and rare earth element and comparison of them with high alkaline and basic rocks of study area indicate they are in related to the within 
plate continental rifting magmatism. The high slope of LREE/HREE in the most of samples is consistent with presence of residual garnet in the mantle source. $\mathrm{The} \mathrm{La} / \mathrm{Yb}_{(\mathrm{Cn})}$ ratios range between 14.95 to 11.75 (averaging 13.1) for FR-10 and FR-13 samples, respectively. This could be in related to the heterogeneity of mantle source or changes in the partial melting degrees of different mantle sources.

\section{References}

[1] Darvishzadeh, A. (2004) Geology of Iran: Stratigraphy, Tectonic, Metamorphism and Magatism. AmirKabir Publication, Tehran, 473 p.

[2] Sheykh Zakariyai, J. (2002) Petrography and Petrology of Magmatic Rocks in the Qorveh Region. MSc Thesis, Islamic Azad University, North Tehran Branch, Tehran, Iran.

[3] Cox, K.G., Bell, J.D. and Pankhurst, R.J. (1979) The Interpretation of Igneous Rocks. Georg, Allen and Unwin, London.

https://doi.org/10.1007/978-94-017-3373-1

[4] Le bas, M.J., Lemaitre, R.W., Streckeisen, A. and Zanettin, B. (1986) A Chemical Classification of Volcanic-Rocks Based on the Total Alkali Silica Diagram. Journal of Petrology, 27, 745-750. https://doi.org/10.1093/petrology/27.3.745

[5] De la Roche, H., Leterrier, J., Grandclaude, P. and Marchal, M. (1980) A Classification of Volcanic and Plutonic Rocks Using $R_{1} R_{2}$-Diagrams and Major Element Analysis-Its Relationships with Current Nomenclature. Chemical Geology, 29, 183-210. https://doi.org/10.1016/0009-2541(80)90020-0

[6] Winchester, J.A. and Floyd, P.A. (1977) Geochemical Discrimination of Different Magma Series Their Differentiation Products Using Immobile Elements. Chemical Geology, 20, 325-345. https://doi.org/10.1016/0009-2541(77)90057-2

[7] Pearce, J.A. (1996) A User's Guide to Basalt Discrimination Diagrams, in Trace Element Geochemistry of Volcanic Rocks: Applications for Massive Sulphide Exploration: Geol. Assoc. Can. In: Wyman, D.A., Ed., Short Course Notes, Vol. 12, Geol. Assoc. of Can., St. John's, Newfoundland, 79-113.

[8] Kuno, H. (1968) Differentiation of Basalt Magmas. In: Hess, H.H. and Poldervaart, A., Eds., Basalts: The Poldervaart Treatise on Rocks of Basaltic Composition, Vol. 2, Interscience, New York, 623-688.

[9] Peccerillo, R. and Taylor, S.R. (1976) Geochemistry of Eocene Calc-Alkaline Volcanice Rocks from the Kastamonu Area, Northern Turkey. Contributions to Mineralogy and Petrology, 58, 63-81. https://doi.org/10.1007/BF00384745

[10] Pearce, J.A. and Norry, M.J. (1979) Petrogenetic Implications of Ti, Zr, Y and Nb Variations in Volcanic Rocks. Contributions to Mineralogy and Petrology, 69, 33-47. https://doi.org/10.1007/BF00375192

[11] Pearce, J.A. and Cann, J.R. (1973) Tectonic Setting of Basic Volcanic Rocks Determined Using Trace Element Analyses. Earth and Planetary Science Letters, 19, 290-300. https://doi.org/10.1016/0012-821X(73)90129-5

[12] Meschede, M. (1986) A Method of Discriminating between Different Types of Mid-Ocean Ridge Basalts and Continental Tholeiites with the Nb-1bZr-1bY Diagram. Chemical Geology, 56, 207-218. https://doi.org/10.1016/0009-2541(86)90004-5

[13] Rollinson, H.R. (1993) Using Geochemical Data, Longman Scientific \& Technical. 
[14] Thompson, R.N., Morrison, M.A., Hendry, G.L. and Parry, S.J. (1984) An Assessment of the Relative Roles of Crust and Mantle in Magma Genesis: An Elemental Approach. Philosophical Transactions of the Royal Society, A310, 549-590. https://doi.org/10.1098/rsta.1984.0008

[15] Thompson, R.N. (1982) British Tertiary Volcanic Province. Scottish Journal of Geology, 18, 49-107. https://doi.org/10.1144/sjg18010049

[16] Fodor, J. (1987) Psychosemantics: The Problem of Meaning in the Philosophy of Mind. MIT Press, Cambridge, MA.

[17] Wood, D.A., Joron, J.L. and Treuil, M. (1979) A Re-Appraisal of the Use of Trace Elements to Classify and Discriminate between Magma Series Erupted in Different Tectonic Settings. Earth and Planetary Science Letters, 45, 326-336. https://doi.org/10.1016/0012-821X(79)90133-X

[18] Sun, S.S. and McDonough, W.F. (1989) Chemical and Isotopic Systematics of Oceanic Basalts; Implications for Mantle Composition and Processes. In: Saunders, A.D. and Norry, M.J., Eds., Magmatism in the Ocean Basins, Geological Society of London, London, Vol. 42, 313-345. https://doi.org/10.1144/GSL.SP.1989.042.01.19

[19] Wilson, M. (1989) Igneous Petrogenesis. Unwin Hyman, London. https://doi.org/10.1007/978-1-4020-6788-4

[20] Boynton, W.V. (1984) Cosmochemistry of the Rare Earth Elements; Meteorite Studies. Elsevier Science Publishing Company, Amsterdam.

[21] Nakamura, N. (1974) Determination of REE, Ba, Fe, Mg, $\mathrm{Na}$ and $\mathrm{K}$ in Carbonaceous and Ordinary Chondrites. Geochimica et Cosmochimica Acta, 38, 757-775.

https://doi.org/10.1016/0016-7037(74)90149-5 